Bangladesh J. Plant Taxon. 24(2): 227-231, 2017 (December)

(C) 2017 Bangladesh Association of Plant Taxonomists

\title{
TWO NEW RECORDS AND ONE REDISCOVERY OF ANGIOSPERMS FOR BANGLADESH
}

\author{
KHANDAKAR KAMRUL ISLAM ${ }^{1}$ AND NAIMUR RAHMAN \\ Bangladesh National Herbarium, Chiriakhana Road, \\ Mirpur-1, Dhaka-1216, Bangladesh
}

Keywords: New records; Rediscovery; Angiosperm; Bangladesh

\begin{abstract}
Two species of angiosperms, Spiradiclis bifida Kurz (Rubiaceae) and Strobilanthes urticifolia Wall. ex Kuntze (Acanthaceae) are being reported as new records for Bangladesh. One species, Corymborkis veratrifolia (Reinw.) Blume belonging to the Orchidaceae has been rediscovered from Hazarikhil Wildlife Sanctuary after about 90 years of last record. These species are described with updated nomenclature, synonyms, taxonomic description, ecology and geographical distribution. Illustrations with field photographs are also provided.
\end{abstract}

\section{Introduction}

During recent botanical explorations in Hazarikhil Wildlife Sanctuary, under Chittagong Forest Division, Chittagong District the authors collected three plant specimens belonging to the families Rubiaceae, Acanthaceae and Orchidaceae. On examining the specimens under Rubiaceae, Acanthaceae and Orchidaceae housed at Bangladesh National Herbarium (DACB), Bangladesh Council of Scientific and Industrial Research, Chittagong (BCSIRH), Herbarium of Bangladesh Forest Research Institute (BFRIH), Dhaka University Salar Khan Herbarium (DUSH) and Herbarium of Chittagong University (HCU)) the specimens did not matched with any specimens stored at those herbaria. Later, these were identified as Spiradiclis bifida Kurz (Rubiaceae), Strobilanthes urticifolia Wall. ex Kuntze (Acanthaceae) and Corymborkis veratrifolia (Reinw.) Blume (Orchidaceae).

Encyclopedia of Flora and Fauna of Bangladesh described a total of 107 taxa of the family Acanthaceae (Begum et al., 2008) and a total of 170 taxa of the family Rubiaceae (Rahman and Das, 2009) for the flora of Bangladesh. Das et al. (2009, 2012 and 2013) and Das and Rahman (2010, 2011) added another 16 species to the account of Rubiaceae. Rahman and Das (2009) recorded only one species under the genus Spiradiclis and Begum et al. (2008a) recorded fourteen species under the genus Strobilanthes.

These two species, Spiradiclis bifida Kurz (Rubiaceae) and Strobilanthes urticifolia Wall. ex Kuntze (Acanthaceae) were not previously recorded from the territory of Bangladesh in the relevant works of Hooker (1880, 1884), Kurz (1877), Prain (1903), Heinig (1925), Cowan (1926), Cowan and Cowan (1929), Kanjilal et al. (1939), Raizada (1941), Datta and Mitra (1953), Sinclair (1956), Rahman and Das (2009), Begum et al. (2008), Islam (2009), Uddin and Rahman (2015), and Rahman et al. (2015). These were recorded by Hooker (1880, 1884 ) from Khasia mountains, upper Assam and Cachar in India and from Pakistan, Nepal and India respectively.

On the other hand, Huda (2008) described a total of 179 taxa of the family Orchidaceae for the flora of Bangladesh. Corymborkis veratrifolia (Reinw.) Blume belonging to the Orchidaceae was recorded from Chittagong and the Chittagong Hill Tracts by Hooker (1890), Prain (1903) and Heinig (1925). Since then it has neither been collected nor recorded to occur else where in

\footnotetext{
${ }^{1}$ Corresponding author. E-mail: orchidcu.islam@gmail.com
} 
Bangladesh. Recently it has been rediscovered from Hazarikhil Wildlife Sanctuary by the authors after about 90 years of last record.

Hence, the species Spiradiclis bifida Kurz and Strobilanthes urticifolia Wall. ex Kuntze are new records and Corymborkis veratrifolia (Reinw.) Blume is a rediscovery for Bangladesh.

\section{Materials and Methods}

Specimens of each species encountered in flowering and fruiting condition were collected and preserved at Bangladesh National Herbarium (DACB). The photographs of fertile specimens in natural habitat were taken during the field trips. Both fresh materials and herbarium specimens were studied and examined by using long arm steriomicroscope. All available taxonomic resources viz. literatures, herbarium specimens and botanical illustrations were taken under consideration to identify the species. Digital images of the species are also used to supplement plant identification and document their habitats. Unnamed specimens were identified and described by consulting relevant floristic literatures of Hooker (1880, 1884), Prain (1903), Rahman and Das (2009), Begum et al. (2008), Huda (2008) and Wu et al. (2011).

Taxonomic enumeration of these two new records and one rediscovery are prepared. In the enumeration, each species is cited with updated nomenclature, commonly known synonyms, taxonomic description, ecology, geographical distribution and citation of voucher specimens deposited at DACB.

\section{Results}

1. Spiradiclis bifida Kurz, J. Asiat. Soc. Beng., Pt. 2, Nat. Hist.. 41(2): 310 (1872). Hook. f., Fl Brit. India 3: 76 (1880).

(Figs. 1a \& 1b)

Herbs, up to $48 \mathrm{~cm}$ tall, apparently perennial. Stems slender. Leaves 10-19×3-7 cm., blade drying thinly papery, elliptic or elliptic-lanceolate; apex acute or shortly acuminate or subcaudate, cuneate at base, adaxially sparsely pilose to subglabrous, abaxially pubescent along veins, secondary veins 15-19 pairs. Petiole 1.5-3.0 cm long, pubescent. Stipules subulate. Inflorescence paniculate, up to $18 \mathrm{~cm}$, simple or bifid axes numerous, $1.0-1.5 \mathrm{~cm}$, scorpioid. Flowers 5-merous, pale creamy, $0.3-0.5 \mathrm{~cm}$ long. Calyx glabrous or subglabrous. Ovary 2 locules. Fruits a capsule, c $0.2 \mathrm{~cm}$ in diam., glabrous or subglabrous, valves 4 . Seeds black.

Flowering and fruiting: January to December.

Habitat: Grows in wet places in deep forest at the slope of the hill about 76-152 m altitude.

Distribution: India (Khasia mountains, upper Assam, Naga hills and Cachar), southern China, Java and Indonesia.

Specimen examined: Chittagong: Hazarikhil Wildlife Sanctuary; 5.11.2015, K.K. Islam and N. Rahman, KKI573 (DACB).

Note: This newly recorded species is nearer to S. cylindrica Wall. ex Hook. f., having leaves $3.0-6.5 \mathrm{~cm}$ long with 7-9 pairs of secondary veins, and white flowers with glabrous sepals.

2. Strobilanthes urticifoliaWall. ex Kuntze, Revis. Gen. Pl. 2: 499 (1891). Strobilanthes alatus Nees, in DC. Prodr. 11:194(1847) (non Blume 1826); Hook. f., Fl Brit. India 4: 464 (1884).

(Figs. 2a \& 2b)

A small erect shrub, up to $1.2 \mathrm{~m}$ tall, with sticky hairy branches, round to 4-angled. Leaves on 2.3-7.9 cm long branchlets, upper leaves sessile and lower ones long petioled, petiole 2.5-6.4 $\mathrm{cm}$ linear or winged upwards, lamina ovate, 7.5-15 $\times$ 4.0-7.5 cm, base cordate, rounded or attenuate, acuminate, serrate. Flowers 5-merous, $2.7-3.8 \mathrm{~cm}$ long, dark-blue, glandular-pubescent 

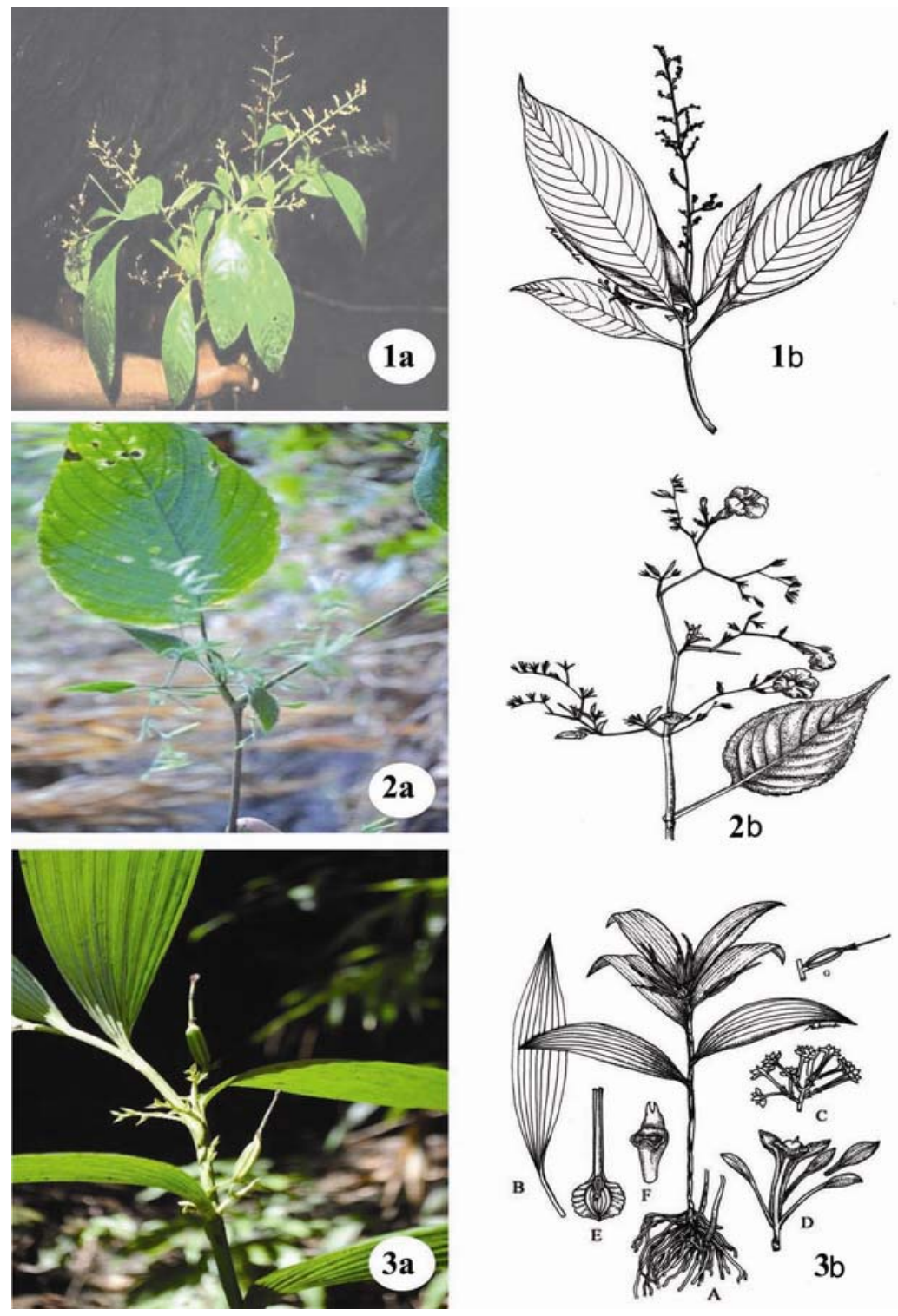

Figs 1-3: 1a. Spiradiclis bifida, 1b. Spiradiclis bifida (Illustration), 2a. Strobilanthes urticifolia, $2 \mathrm{~b}$. Strobilanthes urticifolia (Illustration), 3a. Corymborkis veratrifolia, 3b. (A-G). Corymborkis veratrifolia: A. Habit; B. Leaf; C. Inflorescence; D. Flower; E. Lip with column; F. Front view of column; G. Fruit.

paniculate spikes, c. $2 \mathrm{~cm}$ across, in lax, upper flowers soon in distant pairs, not capitate, tube cylindrical below as long as calyx, limb petals open. Bracts ovate, glandular, deciduous. Calyx 0.6-1.0 cm, deeply divided, linear, obtuse, green, sepals 5, unequal, ligulate, blunt, viscous-hairy, enlarged and accrescent in fruit, one much larger than the rest. Stamens 4, glabrous,staminal filaments dilated. Petals 5, about 1.0-1.3 cm long, ventricose, mouth curved. Ovary 
glandular,hairy;style very remotely minutely hairy; stigma linear c. $0.8-0.9 \mathrm{~cm}$. Capsule c. $1.9 \mathrm{~cm}$ long, narrowly elliptic-oblong, glandular-hairy, 4-seeded. Seeds about $0.9 \mathrm{~cm}$ long, hairy ,ovate.

Flowering and fruiting: November to January.

Habitat: Grows as undergrowth at the top of the hill about 275-305 $\mathrm{m}$ altitude.

Distribution: Pakistan, Afganistan, Nepal and India. It is also found in the Himalayas at altitudes of 2,000-3,500 m.

Specimen examined: Chittagong: Hazarikhil Wildlife Sanctuary; 2.12.2015, K.K. Islam and N. Rahman, NR29 (DACB).

Note: This newly recorded species is nearer to S. dalhousieanus (Nees) C.B. Clarke, having elliptic or ovate-elliptic leaves, flowers in capitate heads or condensed spikes and bracts equal to calyx.

3. Corymborkis veratrifolia(Reinw.) Blume, Coll. Orch. Arch. Ind.: 125(1859). Huda, Ency. Fl. Fa. Bangladesh 12: 32 (2008). Corymbis veratrifolia (Reinw.) Rchb. f., Flora 48: 184 (1865), Hook. f., Fl Brit. Ind. 6: 91 (1890), Prain, Beng. Pl. 2: 772 (1903), Hysteria veratrifolia Rein., Syll. Pl. Nov. 2: 5 (1826).

(Figs. 3a \& 3b)

A rigid terrestrial herb about $1 \mathrm{~m}$ tall. Stem erect, thick, subterete, $0.7-1.3 \mathrm{~cm}$ in diameter. Leaves large, 26-40 × 5-10 cm, narrowly elliptic or elliptic-lanceolate, caudate-acuminate, abaxially often brown scurfy, apex long acuminate, scattered with sheathing bases, basal sheaths 4-10 cm long. Inflorescence a panicle, 10-29 or more flowered, 8-12 cm long, 2-6 branched; bracts at branch base lanceolate, $1.0-1.5 \mathrm{~cm}$, floral bracts ovate, $0.2-0.4 \mathrm{~cm}$. Flowers fragrant, axillary, 2-3 cm across, tubular or campanulate, greenish-white, c. $0.4-0.6 \mathrm{~cm}$. Sepals and petals subsimilar, oblanceolate-linear or narrowly, 3.0-3.7 cm, with the upper one-third deflexed. Lip similar in size with the sepals and other petals, narrowly clawed which encloses the column and flares into an ovate blade with crenulate margin, blade of lip lanceolate, acuminate, apical lobe orbicular or broadly ovate-elliptic with 2 longitudinal ridges. Column c. $3 \mathrm{~cm}$ long, subcylindric, shorter than lip. Pollinia 2, soft, elongated. Rostellum bifid, c. $0.3 \mathrm{~cm}$.

Flowering and fruiting: May to November.

Habitat: Near the streams bank in the dense shade of the deep forest about 15-76 m altitude.

Distribution: Bhutan, Cambodia, India, Indonesia, Japan, Laos, Malaysia, N. Australia, Sri Lanka, SW. Pacific Islands, Taiwan, Thailand and Vietnam. In Bangladesh, the plant was recorded from Chittagong and Chittagong Hill Tracts.

Specimen examined: Chittagong: Hazarikhil Wildlife Sanctuary, 4.11.2015, K.K. Islam and N. Rahman, KKI463 (DACB).

\section{Acknowledgements}

The authors express their gratitude and sincere thanks to Dr. Sarder Nasir Uddin, Principal Scientific Officer, Bangladesh National Herbarium for his kind cooperation to identify these plant specimens. The authors are also grateful to Dr. Mostafa Kamal Pasha, former Professor, Department of Botany, University of Chittagong for his kind cooperation for article preparation.

\section{References}

Begum, M., Afroz, S., Sultana, N. and Hassan, M.A. 2008. Acanthaceae. In: Ahmed, Z.U., Begum, Z.N.T., Hassan, M.A., Khondker, M., Kabir, S.M.H., Ahmad, M., Ahmed, A.T.A., Rahman, A.K.A. and Haque, E.U. (Eds.). Encyclopedia of Flora and Fauna of Bangladesh, Vol. 6. Angiosperms: Dicotyledons (Acanthaceae-Asteraceae). Asiatic Society of Bangladesh, Dhaka, pp. 1-75.

Cowan, J.M. 1926.The flora of the Chakaria Sundarbans. Rec. Bot. Survey India. 11(2): 197-225. 
Cowan, A.M. and Cowan, J.M. 1929. The trees of Northern Bengal- including shrubs, woody climbers, bamboos, palms and tree ferns. Bengal Secretariat Book Dept., Calcutta. pp. 1-178.

Das, S.C., Rashid, M.H. and Rahman, M.A. 2009. Taxonomic revision of the genus Pavetta L. (Rubiaceae) of Bangladesh. Plant Archives 9(2): 813-820.

Das, S.C. and Rahman, M.A. 2010. Notes on the Rubiaceae 3: Five new records for Bangladesh. Bangladesh J. Bot. 39(2): 215-222.

Das, S.C. and Rahman, M.A. 2011. Taxonomic revision of the genus MorindaL. (Rubiaceae) in Bangladesh. Bangladesh J. Bot. 40(2): 113-120.

Das, S.C., Dev, P.K. and Rahman, M.A. 2012. Notes on the Rubiaceae 4: Five new records forBangladesh. Bangladesh J. Bot. 41(1): 21-28.

Das, S.C., Dev, P.K. and Rahman, M.A. 2013. Notes on the Rubiaceae 5: Five new records for Bangladesh. Bangladesh J. Bot. 42(2): 257-264.

Datta, R.M. and Mitra, J.N. 1953. Common plants in and around Dacca. Bull.Bot. Soc. Beng. 7(1\&2): 1-110.

Heinig, R.L.1925. List of Plants of the Chittagong Collectorate and Hill Tracts. The Bengal Government Branch Press, Darjeeling, India. pp. 1-89.

Hooker, J.D. 1890. Orchidaceae. In: Hooker, J.D. (Ed.),The Flora of British India, Vol. 6. The Oast House, Brooke, Ashford, Kent, England. p. 91.

Hooker, J.D. 1880. Rubiaceae. In: Hooker, J.D. (Ed.), The Flora of British India, Vol. 3. The Oast House, Brooke, Ashford, Kent, England. p. 76.

Hooker, J.D. 1884. Acanthaceae, In: Hooker, J.D. (Ed.), The Flora of British India. Vol. 4. The Oast House, Brooke, Asford, Kent, England. p. 464.

Huda, M.K. 2008. Orchidaceae. In: Ahmed, Z.U., Begum, Z.N.T., Hassan, M.A., Khondker, M., Kabir, S.M.H., Ahmad, M., Ahmed, A.T.A., Rahman, A.K.A. and Haque, E.U. (Eds.). Encyclopedia of Flora and Fauna of Bangladesh, Vol. 12. Angiosperms: Monocotyledons (Orchidaceae-Zingiberaceae). Asiatic Society of Bangladesh, Dhaka. p. 32.

Islam, K.K. 2009. Diversity, Ecology, Ethnobotany of Orchids of Madhupur Sal Forest and their conservation. Bangladesh. The University of Chittagong, Chittagong. M.S. Thesis (unpublished). pp. 1218.

Kanjilal, U.N., Das, A., Kanjilal, P.C., and De, R.N. 1939 (Repr. 1982). Flora of Assam, Vol. 3. A Von Book Company, Ajmeri Gate, Delhi, India. pp. 11-95 and 408-457.

Kurz, S. 1877 (Repr. 1974). Forest Flora of British Burma, Vol. 2. Bishen Singh Mahendra Pal Singh, Dehra Dun, India. pp. 4-76 and 239-248.

Prain, D. 1903 (Repr. ed. 1963). Bengal Plants, Vol. 1\&2. Bishen Singh Mahendra Pal Singh, Dehra Dun, India.

Rahman, M.A. and Das, S.C. 2009. Rubiaceae. In: Ahmed, Z.U., Hassan M.A., Begum Z.N.T., Khondaker, M., Kabir, S.M.H., Ahmed, M. and Ahmed, A.T.A. (Eds.). Encyclopedia of Flora and Fauna of Bangladesh, Vol. 10. Angiosperms: Dicotyledons (Ranunculaceae-Zygophyllaceae). Asiatic Society of Bangladesh, Dhaka. pp. 38-159.

Rahman, M.S., Hossain, G.M., Khan, S.A. and Uddin, S.N. 2015. An annotated checklist of the vascular plants of Sundarban mangrove forest of Bangladesh. Bangladesh J. Plant Taxon. 22(1): 17-41.

Raizada, M.B. 1941. On the Flora of Chittagong. Indian Forester 67(5): 245-254.

Sinclair, J. 1956. The Flora of Cox’s Bazar, East Pakistan. Bull. Bot. Soc. Beng. 9(2): 84-116.

Uddin, S.N., and Rahman, N. 2015. Notes on occurrence of the genus Mycetia Reinwardt (Rubiaceae) in Bangladesh. Bull. Bangladesh National Herb. 4:103-110.

Wu, Z. Y., Raven, P. H. and Hong, D. Y. (Eds.) 2011. Flora of China. Vol. 19. Science Press, Beijing and Missouri Botanical Garden Press, St. Louis.

(Manuscript received on 19 October 2017; revised on 6 November 2017) 